\title{
Gene expression of Ceriporiopsis subvermispora during lignocellulosic substrate degradation
}

\author{
SháskyaTanyara Alves do Nascimento Barbosa ${ }^{1 *}$, Zenon M Lima², Priscila Almeida Calixto ${ }^{1}$, Ubiratan Rios Santos ${ }^{1}$, \\ Leandro Eugênio Cardamone Diniz ${ }^{3}$, Jorge A López ${ }^{2}$, Rodrigo Cazzaniga ${ }^{4}$, Maria Lucila Hernández-Macedo ${ }^{2}$ \\ From 5th Congress of the Brazilian Biotechnology Society (SBBIOTEC) \\ Florianópolis, Brazil. 10-14 November 2013
}

\section{Background}

Lignin is a complex aromatic polymer whose microbial degradation is essential for carbon recycling [1]. The fungus Ceriporiopsis subvermispora has attracted attention for its valuable biotechnological applications, especially for pretreatment of lignocellulosic material studies in order to expose the cellulose for hydrolysis and industrial fermentation. Thus, ligninolytic enzymes of white-rot fungi remain the subject of intensive investigations for their potential applications in a wide range of industrial bioprocesses and applications such as the paper industry, textile industry, decolorization of industrial wastewater treatment, and the degradation of organopollutants [2]. The goal of the present work was to grow $C$. subvermispora in coconut fibers as substrate in order to analyze its degradation potential and evaluate the lignin peroxidase expression (Lip1 and Lip2).

\section{Methods}

The fungus was maintained on malt agar at $4^{\circ} \mathrm{C}$. For inoculation, a fungal mycelium suspension $(300 \mu \mathrm{L})$ obtained from $2 \%$ malt extract medium was inoculated on $3 \mathrm{~g}$ of coconut fibers with $10 \mathrm{~mL}$ of sterile distilled water and then incubated at $28^{\circ} \mathrm{C}$ at $15,30,45$, and 60 days. Gene expression was performed by real-time PCR (qPCR) during a cultivation period between 15 to 60 days.

\section{Results and conclusions}

At the experimental interval, rapid fungus colonization on the lignocellulosic substrate was observed. The RTPCR analysis showed that Lip1 gene expression started before the 15th day of cultivation. On the 15th day, this gene was highly expressed and its expression decline was observed from the 45th day. Regarding Lip2, its highest expression was observed in the range between 30 and 45 days of cultivation, while the decrease in the Lip2 expression occurred from the 45th day. Comparing both genes, an abrupt decrease in the Lip1 and Lip2 expression was observed on the 60th day of culture, inferring the possibility that these genes act simultaneously during the degradation of the substrate evaluated. Overall, the results indicate the C. subvermispora potential to degrade coconut fibers, and the gene expression analysis may provide data to understand the fungus extracellular system used to decompose lignin $[3,4]$. Also, insights on the role of regulating elements in the expression of these ligninolytic enzymes are necessary for efficient biotechnological applications.

\section{Acknowledgements \\ Laboratório de Biotecnologia e Biologia Molecular, Embrapa - Tabuleiros Costeiros, SE, Brazil for technical support.}

\section{Authors' details}

${ }^{1}$ Curso de Farmácia, Universidade Tiradentes, Farolândia, Aracaju, SE, Brazil. ${ }^{2}$ Programa de Pós-Graduação em Biotecnologia Industrial, Universidade Tiradentes/Instituto de Tecnologia e Pesquisa, Aracaju, SE, Brazil. ${ }^{3}$ Embrapa Tabuleiros Costeiros, Aracaju, SE, Brazil. ${ }^{4}$ Instituto de Tecnologia e Pesquisa, Aracaju, SE, Brazil.

\section{Published: 1 October 2014}

\section{References}

1. Ruiz-Dueñas FJ, Martínez AT: Microbial degradation of lignin: how a bulky recalcitrant polymer is efficiently recycled in nature and how we can take advantage of this. Microb Biotechnol 2009, 2:164-177.

2. Abdel-Hamid AM, Solbiati JO, Cann IK: Insights into lignin degradation and its potential industrial applications. Adv Appl Microbiol 2013, 82:1-28.

3. Tanaka H, Koike K, Itakura S, Enoki A: Degradation of wood and enzyme production by Ceriporiopsis subvermispora. Enzyme Microb Technol 2009, 45:384-390.

\footnotetext{
${ }^{1}$ Curso de Farmácia, Universidade Tiradentes, Farolândia, Aracaju, SE, Brazil
} Full list of author information is available at the end of the article 
4. Feng $\mathrm{CL}$, Zeng GM, Huang DL, Hu S, Zhao MH, Lai C, Huang C, Wei Z, Li NJ: Effect of ligninolytic enzymes on lignin degradation and carbon utilization during lignocellulosic waste composting. Process Biochem 2011, 46:1515-1520.

doi:10.1186/1753-6561-8-S4-P170

Cite this article as: Nascimento Barbosa et al:: Gene expression of

Ceriporiopsis subvermispora during lignocellulosic substrate degradation. BMC Proceedings 2014 8(Suppl 4):P170.

Submit your next manuscript to BioMed Central and take full advantage of:

- Convenient online submission

- Thorough peer review

- No space constraints or color figure charges

- Immediate publication on acceptance

- Inclusion in PubMed, CAS, Scopus and Google Scholar

- Research which is freely available for redistribution

Submit your manuscript at www.biomedcentral.com/submit 